\title{
RISKS ASSESSMENT ON BUSINESS PLANNING
}

\section{ОЦІНКА РИЗИКІВ ПІД ЧАС ПЛАНУВАННЯ ПІДПРИЕМНИЦЬКОЇ ДІЯЛЬНОСТІ}

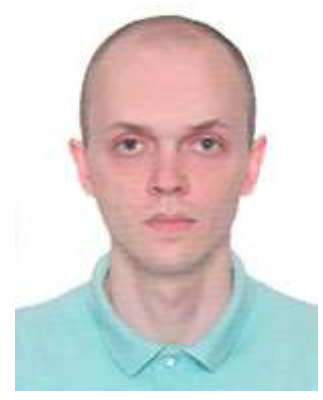

\author{
Kozarchuk Ihor Anatoliyovych. PhD, National Transport University, Associate Pro- \\ fessor Associate Professor of the Department of Transport Construction and Property \\ Management, vigorous@i.ua, Kyiv, Ukraine,+38(093)889-56-46
}

https://orcid.org/0000-0003-4972-6016

Summary. The article studies issues related to risks in entrepreneurial activity. The factors and reasons for its occurrence are analyzed. Methods for risk assessment are reviewed, among which special attention is paid to methods based on mathematical statistics and expert assessments. It is concluded that risk has a positive effect - it stimulates enterprises to improve the business planning system.

Key words: entrepreneurship, business planning, risk assessment, mathematical statistics.

Introduction. In the context of market economy, each enterprise, regardless of its size, form of ownership or type of activity, does planning. For newly created companies, effective planning helps to avoid mistakes in business activities that may cause bankruptcy. In existing enterprises, the need for planning may arise in connection with changes in the production organization, its technical and technological support, mechanisms of product sales, etc. [10]. Planning is also a prerequisite for investing in an enterprise, as investors seek a clear perspective and guarantees of receiving their money back with some profit.

Business plan is an integral part of a business project in countries with a developed economy. The need for its working out is due to the fact that the risk of bankruptcy for newly created enterprises is quite significant, especially in the first 3-5 years [10]. The main reason for failures is the choice of the wrong way in planning of their own activities. Therefore, the ability to compile a business plan is a rather urgent task that necessitates constant analysis of changes in the environment in order to timely adjust the chosen business strategy.

The Economic Code of Ukraine [5] states that "Entrepreneurship is an independent, initiative, systematic, at its own risk, economic activity carried out by economic entities (entrepreneurs) in order to achieve economic and social results and profit". That is, the ability and readiness for risk is an essential part of an entrepreneur.

The development of entrepreneurship in Ukraine necessitates the study of risk issues. The emergence of risk situations can be due to the following factors:

- unplanned changes in internal and external conditions of activity;

- availability of alternative solutions;

- probability of loss occurrence;

- probability of obtaining additional profit.

In a situation of political and economic instability, the degree of risk increases significantly. In the current conditions of Ukraine's economic development, the problem of risk enhancement is very urgent, as evidenced by data on the growth of the loss-making rate of industrial enterprises [6].

Науково-технічний збірник «АВТОмОБІльні дОРОГИ І дОРОЖнє БУдІвницТВО» http://addb.ntu.edu.ua ISSN 0365-8171 (Print), ISSN 2707-4080 (Online), ISSN 2707-4099 (CD).

AUTOMOBILE ROADS AND ROAD CONSTRUCTION, 2021. Issue 109 
Publications analysis. The study of risk assessment in the planning of entrepreneurial activity was undertaken by such authors as J. Mill, N. Senior, F. Knight, J. Keynes, V.A. Beloshapka [1], Z.S. Varnaliy [2], T.H. Vasil'tsiv [3], I.V. Hoy [4], L.I. Donets' [6], V.V. Zyan'ko [7], F. Kotler [8], A.M. Mel'nikov [9], L.S. Shevchenko [10] and others.

For the first time, the notion of "entrepreneur" in the scientific use was introduced by the English economist R. Cantillion. Cantillon also made a systematic analysis of entrepreneurship. He interpreted entrepreneurship as an economic function of a special kind and emphasized the always present element of risk in it.

The study of risk as an economic category was initiated by J. Mill and N. Senior. They associated the reason for economic risk, first of all, with entrepreneurial activity and investigated it in terms of compensation for possible loss. Later, the American economist F. Knight clarified that economic risk is not just a material loss but a consequence of uncertainty in profits. In his work "Risk and Uncertainty", F. Knight noted that risk is an objective probability that an event will occur. Therefore, the risk can be expressed quantitatively, in particular, in the form of a formalized mathematical probabilistic distribution of revenues. J. Keynes associated the economic (in particular, financial) risk with the unpredictability of market prices and excess of worked out equipment [7].

Materials and Methods. The purpose of the article is to investigate the factors of risk occurrence in entrepreneurial activity and methods of their assessment during business planning which are based on methods of mathematical statistics and probability theory.

Results and Discussion. The entrepreneur's risk function consists in the need to make decisions that are aimed at success, but do not guarantee it because of the uncertainty and the variability of the economic situation. An entrepreneur risks not only his own property and investment, but also his work, time and business reputation [2].

Risk assessment is one of the sections of a business plan. The purpose of this section is to identify, minimize and neutralize risks.

Risk is usually interpreted as a likelihood (threat) of the loss of part of enterprise resources, lack of income or the emergence of additional costs as a result of the implementation of certain production and financial activities.

Factors that determine the level of riskiness of entrepreneurial activities and in many ways adversely affect the result of entrepreneurial activity, can be divided into external and internal [2, 3, 6, 7, 9]. External ones include:

- unstable, contradictory legislation;

- unforeseen actions of government agencies;

- instability of economic (financial, tax, foreign economic, etc.) policy;

- political, social and economic instability;

- unforeseen changes in the domestic and foreign market conditions;

- unforeseen competitor actions;

- corruption, racket;

- emergence of new technical and technological advances that can lead to the rapid moral aging of the product;

- unplanned changes in relationships with partners;

- cycling sales volumes;

- cycling cash flow;

- spontaneous forces and climate.

Internal factors include:

- unplanned changes in the production process (equipment breakdown);

Науково-технічний збірник «АвтОмОБльні доРОги І доРОжнє БУдІвництво» $\underline{\text { http://addb.ntu.edu.ua }}$ ISSN 0365-8171 (Print), ISSN 2707-4080 (Online), ISSN 2707-4099 (CD).

AUTOMOBILE ROADS AND ROAD CONSTRUCTION, 2021. Issue 109 
- unplanned changes in the domestic economy;

- lack of business information at the company;

- absence of marketing service;

- financial problems within the firm;

- lack of personnel motivation;

- insufficient competence of managers, specialists and workers;

- non-compliance with the terms of the contracts by the management of the firm;

- difficulties in obtaining materials, components and loans;

- risk aversion among the management of the firm;

- errors in making decisions;

- illness or death of leading specialists.

Different methods can be applied to assess business risk. The most common are three groups of methods [6]:

- $\quad$ statistical methods;

- methods of expert assessments;

- calculation-analytical methods.

Statistical methods consist in studying the statistics of losses and profits in a given or similar enterprise in order to determine the probability of an event and assess the value of risk. That is, the quantitative assessment of entrepreneurial risk is carried out using methods of mathematical statistics. However, statistical methods are not suitable if the object of research is a newly established company.

Method of expert estimation. If the use of statistical methods is impossible (for example, due to lack of reliable information), methods based on the use of experience and intuition of experts, that is heuristic or methods of expert estimation, are applied. The peculiarity of this method is the lack of a clear mathematical ground for the optimality of solutions.

Calculation-analytical methods. The essence of such methods is that the costs for each activity, as well as its individual elements, have different degrees of risk. For example, the risk degree of costs associated with the acquisition of raw materials will be higher than the cost of wages.

The following indicators are used to assess the risk degree:

- in absolute terms, the risk is defined as the magnitude of possible losses in the material or value measurement;

- in relative terms, risk is determined as a percentage by dividing the value of possible losses by the index of the financial condition of the enterprise (cost of property (funds), current expenses, investment or expected profit);

- since risk is a probabilistic random category, it is characterized not only by magnitude, but also by the probability that it will reach this magnitude. Therefore, methods of probability theory and statistics are used to calculate the risk degree.

Based on the practice, foreign specialists believe that one can focus on the following limit values of probability of risk of loss [4]:

- for an acceptable risk, which is equal to profit $-0,1$;

- for a critical risk, equal to income - 0,01;

- for a catastrophic risk, equal to the value of the property $-0,001$.

This means that you should not sign a contract, if in one case out of ten you can lose all profits, in one out of hundred - revenue, and in one out of thousand - all the capital.

According to studies conducted in western countries, the bankruptcy of small firms in $98 \%$ of cases is due to poor management and only $2 \%$ are not dependant on the firm.

Науково-технічний збірник «АвТОмОБІльні дОРОГи г дОРОжНє БУдІВНИЦТВО» http://addb.ntu.edu.ua

ISSN 0365-8171 (Print), ISSN 2707-4080 (Online), ISSN 2707-4099 (CD).

AUTOMOBILE ROADS AND ROAD CONSTRUCTION, 2021. Issue 109 
The risk management process involves analysis, quantification and methods for risk reduction (or complete elimination).

The essence of qualitative analysis is to determine the risk factors and types of work in which it occurs. At this stage, the actions of risks identification are specified. This is a comprehensive analysis of various forms of enterprise reporting and surveys of experts.

The quantitative assessment consists in establishing the relationship between the economic risk factors and the main results of the operating activity of the enterprise and determining the value of risk using statistical, analytical and other methods.

Quantitatively, the probability of occurrence of a certain financial loss of an enterprise can be calculated as follows:

$$
P_{i}=\frac{m}{n}
$$

where $P_{i}$ is the probability of occurrence of the $i$-th volume of loss;

$m$ - number of real cases of this volume of loss to happen;

$n$ - total number of events (elements) that are studied in aggregate.

The criterion for a quantitative assessment of a risk is the probability of obtaining a result smaller than the required (acceptable) value:

$$
K=P \cdot\left(R_{p}-R_{f}\right)
$$

where $P$ - probability of occurrence of a risk situation;

$R_{p}$ - value of the planned result (required);

$R_{f}-$ obtained result (actual).

An absolute value is taken as a criterion of a quantitative risk - the degree of risk:

where $C$ - expected loss;

$$
K=C \cdot P,
$$

$P$ - probability of loss.

Approaches to risk assessment can also be reduced to the following three groups:

1) risk is estimated as a sum of the products of possible losses, weighted considering their probability;

2) risk is estimated as a sum of the risks from the decision making and the risks of the environment (independent of internal decisions);

3) risk is defined as the product of the probability of occurrence of a negative event and the degree of negative consequences.

The most common methods of risk assessment are [3, 7]:

1. Method of discount rate adjusting. The essence of the method is to bring flows of future payments to the present moment (discounting the future value of financial resources).

2. Method of reliable equivalents (probability coefficients). It consists in establishing the coefficients of probability adequately for each type of risk and reducing the expected revenues of financial resources by their magnitude.

3. Sensitivity analysis. Illustrates an influence of individual input factors on the final result of the entrepreneurial activity (implementation of a business project).

In the process of sensitivity analysis, the dependence of performance indicators (financial result) of the project on the changes of one of the selected parameters whose value varies in the specified small range $( \pm 5 \%$, $\pm 10 \%$, etc.) with fixed values of other parameters is determined. Parameters that change during the sensitivity 
analysis are divided into two main groups: those that affect the volume of revenues and those that affect the volume of expenditure. As a result of the analysis, for all ambiguous factors a chart or a table of sensitivity is made, relying on which the project effectiveness can be concluded.

Using objective method, the probability of event occurrence is determined by calculating the frequency of its occurrence.

Important indicators, on the basis of which it is possible to draw conclusions about a risk degree of a business project, are: dispersion, standard deviation and coefficient of variation.

Dispersion is the measure of the deviation of the actual parameters of the variation range from its mean value. The latter characterizes the average financial result of a particular operation (enterprise activity) and is determined by the formula:

$$
F=\sum_{i=1}^{n}\left(F_{i} \cdot P_{i}\right)
$$

where $F_{i}-i$-th possible financial result, monetary units;

$P_{i}$ - probability of occurrence of $i$-th financial result.

The dispersion $\delta^{2}$ is defined as the weighted average of squares of the deviation of the actual financial results of the investigated business operations from the average value within the variation range:

$$
\delta^{2}=\sum_{i=1}^{n}\left(F_{i}-F\right)^{2} \cdot P_{i}
$$

The dispersion signals the presence of risk, but it doesn't show the direction of deviation from the expected value. An entrepreneur often needs to know what is the most likely result of a bargain - a loss or a profit.

The mean square deviation (standard deviation) $\delta$ is defined as:

$$
\delta=\sqrt{\delta^{2}}
$$

The mean square deviation describes the weighted average (most probable) magnitude of the variation of individual variants (possible financial consequences of economic operations) from their average value.

The coefficient of variation $(v)$, which is defined as the ratio of the mean-square deviation to the mean value of the variant, is also used to compare the variations of different statistical sets:

$$
v=\frac{\delta}{F} .
$$

The higher the value of the mean-square deviation and the coefficient of variation, the higher the risk is.

The subjective method is based on subjective assessments of experts, consultants or entrepreneur's personal experience.

To reduce the risk and improve the reliability of the project, an analysis of its sensitivity is carried out, that is, the level of impact of the main (critical) factors on the efficiency (payback period, profitability, etc.) is determined. Following factors are usually considered: unit price; sales volume; unit cost price; inflation rate 
in the planned period; delay of payments for shipped products, etc. As a result of sensitivity analysis on the planning stage, measures that reduce the risk degree in the project implementation are also provided.

It is advisable to carry out the sensitivity analysis in relation to risk, which is difficult to eliminate by traditional methods for risk minimization, because it is present systematically due to external factors and depends on the activity of a particular company or industry. This risk is called systematic and is expressed by the sensitivity coefficient $\beta(8)$. It determines the level of fluctuations in the results of the industry in relation to the results of the market or the economy as a whole. However, this indicator can also be used to determine the level of fluctuation of the results of an individual enterprise in relation to the results of the industry in which it operates.

Given the statistical data on the profitability of a particular ( $i$-th) type of securities, the sensitivity coefficient is determined using following expression:

$$
\beta_{i}=\frac{\operatorname{cov}\left(D_{i}, D_{m}\right)}{\delta^{2}\left(D_{m}\right)}=\frac{\sum_{j=1}^{n}\left(D_{m j}-\bar{D}_{m}\right)\left(D_{i j}-\bar{D}_{i}\right)}{\sum_{j=1}^{n}\left(D_{m j}-\bar{D}_{m}\right)^{2}}
$$

where $n$ - number of $j$-ths time intervals in the investigated period (interval of sampling);

$D_{i}, D_{m}$ - yield of the $i$-th type of shares and average market yield respectively;

$\operatorname{cov}\left(D_{i}, D_{m}\right)$ - yield covariance of the $i$-th type of shares and average market yield;

$\delta^{2}\left(D_{m}\right)$ - dispersion of the average market yield of shares; tively;

$D_{i j}, D_{m j}$ - yield of the $i$-th type of shares and the average market yield for the $j$-th time interval respec-

$\bar{D}_{i}, \bar{D}_{m}$ - average yield of the $i$-th type of shares and the average market yield for the entire period respectively.

A scale is used to describe $\beta$ (Table 1). The range of values from 0 to 2 is recommended for estimating the coefficient $\beta$ using expert method.

Table 1 - Scale of coefficients of systematic enterprise risk $(\beta)$

Таблиця 1 - Шкала коефіцієнтів систематичного ризику підприємства $(\beta)$

\begin{tabular}{|c|l|}
\hline$\beta$ & \multicolumn{1}{|c|}{ Risk grading } \\
\hline 0 & no risk \\
\hline$(0 . .1)$ & risk value is below average \\
\hline 1 & risk value is at the market average level \\
\hline$(1 . .2)$ & risk value is higher than the market average \\
\hline
\end{tabular}

An application importance of the coefficient $\beta$ is the possibility to estimate how much the expected revenue on a specific type of shares compensates for the riskiness of investments in these shares. That is, this indicator allows to determine what should be the yield of a risky action depending on the average market yield $D_{m}$ at the given time and the yield of risk-free investments $D_{0}$ :

$$
D_{i}^{\prime}=D_{0}+\beta\left(D_{m}-D_{0}\right)
$$

where $D_{0}$ is a yield rate that has a risk equal to 0 . The National Bank's rate on state debt securities can be taken as a $D_{0}$.

Науково-технічний збірник «АвтОмОБльні доРОги І доРОжнє БУдІвництво» http://addb.ntu.edu.ua ISSN 0365-8171 (Print), ISSN 2707-4080 (Online), ISSN 2707-4099 (CD).

AUTOMOBILE ROADS AND ROAD CONSTRUCTION, 2021. Issue 109 
4. The method of scenarios. Using the analysis of sensitivity, key factors of an investment project are determined. Possible situations caused by fluctuations of these factors are considered (the "tree of scenarios" is being built). The method of expert estimation determines the probabilities of each scenario. For each scenario, considering its probability, an array of net current values of the project is calculated. The risk criteria of the enterprise (or its project) are calculated based on the data of this array.

Thus, the scenario analysis involves forecasting by highly skilled experts of several possible scenarios and related dynamics of main indicators of the project. Probabilities measured in this way are subjective probabilistic situations. According to assumptions, a reassessment of the project cost for pessimistic and optimistic versions is being made. The main advantage of the scenario approach is that it does not require knowledge of the laws of the distribution of probabilistic changes for major market factors. However, the drawback is that any scenario assessments have an imprint of subjectivity [7].

5. Analysis of probabilistic distribution of payment flows. The application of this method for risk analysis provides an opportunity to obtain useful information about the expected values of net present value of a project and net income, as well as to analyse their probabilistic distributions.

6. Method of decision tree. Used in situations where decisions taken at a certain time are dependent on decisions taken earlier, and in turn determine scenarios for the further development of events.

7. Monte Carlo method (simulation modelling). The method is based on economic-statistical methods and game theory. The simulation modelling algorithm involves the following steps: determining the key factors of an investment project (using sensitivity analysis); defining the maximum and minimum values of key factors; choosing the distribution type of probabilities; performing simulation of key factors; calculating the criteria that quantitatively characterise the risk of an investment project (mathematical expectation of net present value, dispersion, mean square deviation, etc.).

An alternative way of considering uncertainty is to use the theory of fuzzy sets. It provides a possibility to propose a method for assessment of investment risk basing on the of complex indicator of estimation of a risk degree $(\omega)[3]$ :

$$
\begin{aligned}
& \omega=R\left(1+\frac{1-\lambda}{\lambda} \ln (1-\lambda)\right), \\
& \lambda=-\frac{N P V_{\text {min }}}{N P V_{\text {avg }}-N P V_{\text {min }}}, \\
& R=-\frac{N P V_{\text {min }}}{N P V_{\text {max }}-N P V_{\text {min }}}, \\
& N P V_{\text {min }}=\sum_{t=1}^{n}\left(\frac{C F_{\text {min }}}{\left(1+R D_{\max }\right)^{t}}\right)-I, \\
& N P V_{\text {max }}=\sum_{t=1}^{n}\left(\frac{C F_{\text {max }}}{\left(1+R D_{\text {min }}\right)^{t}}\right)-I, \\
& N P V_{\text {avg }}=\sum_{t=1}^{n}\left(\frac{C F_{\text {avg }}}{\left(1+R D_{\text {avg }}\right)^{t}}\right)-I,
\end{aligned}
$$

Науково-технічний збірник «АвтомОБІльні дОРОГи г доРОжнє БУдІвництво» http://addb.ntu.edu.ua ISSN 0365-8171 (Print), ISSN 2707-4080 (Online), ISSN 2707-4099 (CD).

AUTOMOBILE ROADS AND ROAD CONSTRUCTION, 2021. Issue 109 


$$
\begin{gathered}
C F_{\text {avg }}=\frac{C F_{\max }-C F_{\text {min }}}{2}, \\
R D_{\text {avg }}=\frac{R D_{\text {max }}-R D_{\text {min }}}{2},
\end{gathered}
$$

where $N P V_{\min }, N P V_{\max }, N P V_{\text {avg }}$ - minimum, maximum and average value of net present value respectively, monetary units;

$C F_{\min }, C F_{\max }, C F_{\text {avg }}$ - respectively the minimum, maximum and average net cash flow (income minus costs) for period $t$;

$R D_{\min }, R D_{\max }, R D_{\text {avg }}$ - minimum, maximum and average annual discount rate respectively;

$I$ - amount of investment in the implementation of the investment project, monetary units;

$n-$ number of the last investigated period (investment horizon).

Conclusions and Recommendations. Risk is an integral part of entrepreneurial activity in a market economy. Therefore, the risk should be considered when developing a business plan of an enterprise. A lot of attention should be given to the creation of an effective risk management system both at the enterprise level and at the state level when implementing or regulating economic activity. This guarantees the stability of the entrepreneurship functioning. Positive side of risk appears in the fact that the its presence is a strong incentive for economic entities to rational use of productive resources, thorough analysis of activity profitability, considering investment estimates and selecting skilled personnel.

\section{References}

1. Beloshapka V.A. Strategycheskoe upravleniye: printsypy i mezhdunarodnaya praktika [Strategic management: principles and international practice]. Kiev, KGEU, 1999. 351 p.

2. Varnaliy Z.S. Osnovy pidpryyemnytstva: navch. posib [Basics of entrepreneurship: teaching manual]. Kyiv, Znannya-Pres, 2002. 239 p.

3. Vasyl'tsiv T.H., Kachmaryk Ya.D., Blons'ka V.I., Lupak R.L. Biznes-planuvannya: navch. posib. [Business Planning: teaching manual]. Kyiv, Znannya, 2013. 173 p.

4. Hoy I.V., Smelyans'ka T.P. Pidpryyemnytstvo: navch. posib. [Entrepreneurship: teaching manual]. Kyiv, Tsentr uchbovoyi literatury, 2013. 368 p.

5. Hospodars'kyy kodeks Ukrayiny [Economic Code of Ukraine]. Vidomosti Verkhovnoyi Rady Ukrayiny. 2003, Issue 18, 19-20, 21-22, p.144.

6. Donets' L.I., Romanenko N.H. Osnovy pidpryyemnytstva: navch. posib. [Basics of entrepreneurship: teaching manual]. Kyiv: Tsentr navchal'noyi literatury, 2006. 320 p.

7. Zyan'ko V.V. Innovatsiyne pidpryyemnytstvo: sutnist', mekhanizmy i formy rozvytku [Innovative entrepreneurship: the essence, mechanisms and forms of development]. Vinnytsya, UNIVERSUM - Vinnytsya, 2008. $397 \mathrm{p}$.

8. Kotler F. Osnovy marketynga [Basics of Marketing]. Moscow, Progress, 1990. 736 p.

9. Mel'nykov A.M., Kovalenko O.A., Pundyak N.B. Osnovy orhanizatsiyi biznesu: navch. posib. [Basics of business organization: teaching manual]. Kyiv, Tsentr uchbovoyi literatury, 2013. $200 \mathrm{p}$.

10.Shevchenko L.S. Ekonomika pidpryyemstva: navch. posib. [Economics of Business: teaching manual]. Kharkiv, Nats. un-t «Yuryd. akad. Ukrayiny im. Yaroslava Mudroho», 2011. 208 p.

\section{ОЦІККА РИЗИКІВ ПІД ЧАС ПЛАНУВАННЯ ПІДПРИЕМНИЦЬКОЇ ДІЯЛЬНОСТІ}

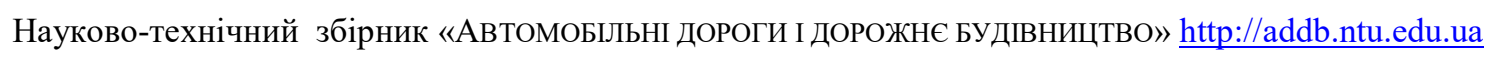
ISSN 0365-8171 (Print), ISSN 2707-4080 (Online), ISSN 2707-4099 (CD).

AUTOMOBILE ROADS AND ROAD CONSTRUCTION, 2021. Issue 109 
Козарчук Ігор Анатолійович. кандидат технічних наук, Національний транспортний університет, доцент кафедри транспортного будівництва та управління майном, vigorous@i.ua, Київ, Україна, +38(093) 889-56-46. Number ORCID: https://orcid.org/0000-0003-4972-6016

Розвиток підприємництва в Україні зумовлює необхідність вивчення проблем, пов'язаних з ризиками, оскільки ризики - невід’ємна частина підприємницької діяльності. Виникнення ризикових ситуацій може обумовлюватися такими чинниками: непередбачені зміни у внутрішніх і зовнішніх умовах діяльності; наявність альтернативних рішень; імовірність виникнення збитків; імовірність одержання додаткового прибутку. Особливо сильно ступінь ризику зростає в умовах політичної й економічної нестабільності. Тому дослідження цієї проблеми $є$ нагальним у сучасних умовах розвитку економіки України, а стаття $є$ актуальною. Також в статті аналізуються фактори і причини виникнення підприємницького ризику. Розглядаються методи оцінки ризику, серед яких особливу увагу приділено методам (як найбільш точним, обгрунтованим і практичним), які грунтуються на математичній статистиці та експертних оцінках. Зроблено висновок про позитивний ефект ризику - він стимулює суб'єкти господарювання вдосконалювати систему бізнес-планування, раціонально використовувати виробничі ресурси, змушує підприємців ретельно аналізувати рентабельність своєї діяльності, розглядати інвестиційні кошториси, підбирати кваліфіковані кадри.

Ключові слова: підприємництво, бізнес-планування, оцінка ризиків, математична статистика.

\section{Перелік посилань}

1. Белошапка В.А. Стратегическое управление: принципы и международная практика / В.А. Белошапка. - Киев: КГЭУ, 1999. - 351 с.

2. Варналій 3.С. Основи підприємництва: навч. посіб. / З.С. Варналій - Київ: Знання-Прес, 2002. $-239 \mathrm{c}$.

3. Васильців Т.Г. Бізнес-планування : навч. посіб. / Т.Г. Васильців, Я.Д. Качмарик, В.І. Блонська, Р.Л. Лупак. - Київ: Знання, 2013. - 173 с.

4. Гой І.В. Підприємництво : навч. посіб. / І.В. Гой, Т.П. Смелянська. - Київ: «Центр учбової літератури», 2013. - $368 \mathrm{c}$.

5. Господарський кодекс України // Відомості Верховної Ради України. - 2003, № 18, № 19-20, № 21-22, ст.144.

6. Донець Л.І., Романенко Н.Г. Основи підприємництва : навч. посіб. / Л.І. Донець, Н.Г. Романенко. - Київ: Центр навчальної літератури, 2006. - 320 с.

7. Зянько В.В. Інноваційне підприємництво: сутність, механізми і форми розвитку / В.В. Зянько. - Вінниця: УНІВЕРСУМ - Вінниця, 2008. - 397 с.

8. Котлер Ф. Основы маркетинга / Ф. Котлер. - Москва: Прогресс, 1990. - 736 с.

9. Мельников А.М. Основи організації бізнесу : навч. посіб./ за заг. ред. А.М. Мельникова [А.М. Мельников, О.А. Коваленко, Н.Б. Пундяк]. - Київ: «Центр учбової літератури», 2013. - 200 с.

10.Шевченко Л.С. Економіка підприємства : навч. посіб. / за заг. ред. Л. С. Шевченко. - Харків: Нац. ун-т «Юрид. акад. України ім. Ярослава Мудрого», 2011. - 208 с.

Науково-технічний збірник «АвТОмОБІльні дОРОГи г дОРОжНє БУдІВНИцТВО» http://addb.ntu.edu.ua ISSN 0365-8171 (Print), ISSN 2707-4080 (Online), ISSN 2707-4099 (CD).

AUTOMOBILE ROADS AND ROAD CONSTRUCTION, 2021. Issue 109 